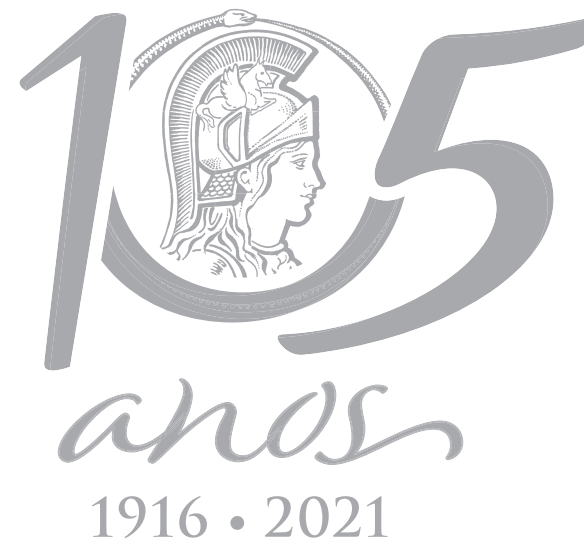

$1916 \cdot 2021$

\title{
Evaluation of the genetic toxicity of sofosbuvir and simeprevir with and without ribavirin in a human-derived liver cell line
}

\author{
CARINA S. LIBRELOTTO, ANA PAULA DE SOUZA, MÁRIO R. ÁLVARES-DA-SILVA, \\ DANIEL SIMON \& RAFAEL R. DIHL
}

\begin{abstract}
Direct-acting antivirals have revolutionized the treatment of chronic hepatitis C. Sofosbuvir and simeprevir are prescribed worldwide. However, there is a scarcity of information regarding their genotoxicity. Therefore, the present study assessed the cytotoxic and genotoxic effects of sofosbuvir and simeprevir, alone and combined with ribavirin. HepG2 cells were analyzed using the in vitro cytokinesis-block micronucleus cytome assay. Cells were treated for $24 \mathrm{~h}$ with sofosbuvir (0.011-1.511 mM), simeprevir (0.156-5.0 $\mu \mathrm{M})$, and their combinations with ribavirin (0.250-4.0 mM). No significant differences were observed in the nuclear division cytotoxicity index, reflecting the absence of cytotoxic effects associated to sofosbuvir. However, the highest concentration of simeprevir showed a significant difference for the nuclear division cytotoxicity index. Moreover, significant results were observed for nuclear division cytotoxicity index in two combinations of sofosbuvir plus ribavirin and only in the highest combination of simeprevir plus ribavirin. Additionally, our results showed that sofosbuvir did not increase the frequency of chromosomal damage, but simeprevir significantly increased the frequency of micronuclei at the highest concentrations. The combination index demonstrated that both sofosbuvir and simeprevir produced antagonism to the genotoxic effects of ribavirin. In conclusion, our results showed that simeprevir, but not sofosbuvir, has genotoxic effects in HepG2 cells.
\end{abstract}

Key words: direct-acting antiviral, micronucleus test, sofosbuvir (CAS 1190307-88-0), simeprevir (CAS 923604-59-5), ribavirin (CAS 36791-04-5).

\section{INTRODUCTION}

Chronic hepatitis C affects approximately 71 million people worldwide, or about $1 \%$ of the world's population (WHO 2017). Chronic hepatitis $C$ is an infectious disease caused by the hepatitis $\mathrm{C}$ virus ( $\mathrm{HCV}$ ) and is the leading cause of liver diseases such as liver cirrhosis and hepatocellular carcinoma (Sebastiani et al. 2014). In this sense, antiviral therapy is an important tool in the control of the epidemic, when the main objective is sustained virological response (SVR) (González-Grande et al. 2016).
SVR is defined as the absence of detectable HCV by nucleic acid testing in blood samples obtained 12-24 weeks after completion of HCV therapy (Wiktor \& Scott 2017).

Treatment for HCV has evolved significantly in recent years, especially with the licensing of new direct acting antiviral drugs (DAAs). DAAs are antivirals that specifically block the action of viral proteins during the HCV replication cycle, such as nonstructural proteins NS3/4A (protease inhibitors), NS5A (NS5A inhibitors), and NS5B (polymerase inhibitors) (Geddawy et al. 2017). The only therapeutic option for 
treatment of HCV infection prior to 2011 was pegylated interferon alfa (PegIFNa) and ribavirin (RBV) for 24-48 weeks, depending on the HCV genotype (Flisiak et al. 2017a). In 2011, boceprevir and telaprevir, the first protease inhibitors, were approved for the treatment of HCV genotype 1 infection (Jacobson et al. 2011, Poordad et al. 2011). However, these drugs have been reported to have limited efficacy and severe adverse effects, and in 2013 they were largely replaced by newer DAAs, including sofosbuvir (SOF), daclatasvir and simeprevir (SIM).

The approval of SOF by the Food and Drug Administration (FDA) represented a milestone in the development of new therapeutic options, and created new perspectives in the development of potent treatment regimens for chronic hepatitis C. Thus, these new DAAs and their combinations revolutionized HCV treatment, with shorter treatment regimens, lower toxicity, and more effective response (SVR > 90\%) (Geddawy et al. 2017). SOF is an oral nucleotide analogue inhibitor of the HCV-specific NS5B polymerase with high antiviral efficacy across all genotypes, though it should never be used in monotherapy (González-Grande et al. 2016, Geddawy et al. 2017).

Due to its pangenotypic mode of action, SOF is an important component in HCV therapy, being part of several treatment regimens for different genotypes (Geddawy et al. 2017). Several studies have demonstrated a favorable clinical safety profile of SOF-based treatment regimens (Liu et al. 2014, Beck et al. 2016, Calleja et al. 2017, Crespo et al. 2017, Flisiak et al. 2017b, Yang \& Choi 2017); however, few studies have investigated its genotoxic profile (FDA 2013a, EMA 2016). The genotoxic effects of RBV have already been demonstrated in cell culture studies (Joksić et al. 2000, 2006, Librelotto et al. 2019), but there are few studies evaluating the genotoxic effects of DAAs, which are often used in combination.
In this sense, the present study assessed the cytotoxic and genotoxic potentials of two DAAs (SOF and SIM), with and without RBV, using the in vitro cytokinesis-block micronucleus cytome (CBMN-Cyt) assay in human hepatoma cells (HepG2).

\section{MATERIALS AND METHODS}

\section{Chemical agents}

SOF (SovaldiтM) was manufactured by Gilead Sciences (Foster City, CA, USA) and diluted with DMSO (Dimethyl Sulfoxide; CAS 67-68-5; Sigma-Aldrich, St. Louis, MO, USA) plus DMEM (Dulbecco's Modified Eagle's Medium; Gibco ${ }^{\circledR}$ Invitrogen, Carlsbad, CA, USA). SIM (Olysio ${ }^{\mathrm{TM}}$ ) was manufactured by the company JanssenCilag International NV (Beerse, BE, EU) and was diluted with DMEM. RBV was manufactured by Farmanguinhos (Rio de Janeiro, Brazil) and diluted with DMEM. The chemical mutagen benzo[a]pyrene (B[a]P) (CAS 50-32-8) was purchased from Sigma-Aldrich (St. Louis, MO, USA) and was used as positive control at $1 \mu \mathrm{M}$. The negative control of the SOF experiments was DMEM plus DMSO (1\%) and of the SIM experiments was DMEM. All dilutions were prepared immediately before use.

\section{Cell line and culture conditions}

HepG2 cells were purchased from Rio de Janeiro Cell Bank (HepG2 catalogue 0103). HepG2 cells was maintained as a monolayer in $75 \mathrm{~cm}^{2}$ flasks in DMEM supplemented with 10\% heat-inactivated foetal bovine serum (Cultilab ${ }^{\circledR}$, Campinas, SP, Brazil) and antibiotics (0.1\% gentamicin and 1\% penicillin and streptomycin, both from Gibco ${ }^{\circledR}$ Invitrogen, Carlsbad, CA, USA) and kept in a humidified $5 \% \mathrm{CO}_{2}$ atmosphere at $37^{\circ} \mathrm{C}$ until confluence was reached. 


\section{The cytokinesis-block micronucleus cytome (CBMN-Cyt) assay}

The CBMN-Cyt assay was carried out according to Fenech (2007) with slight modifications. Briefly, HepG2 cells were seeded on 24-well plates at the density of $1 \times 10^{5}$ and incubated for $20 \mathrm{~h}$ at $37^{\circ} \mathrm{C}$ and $5 \% \mathrm{CO}_{2}$. The concentrations of SOF and SIM to be tested in the CBMN-Cyt assay were determined based on the solubility of both compounds in the medium. Then, HepG2 cells were exposed to a 24-h treatment with SOF $(0.011,0.023,0.047,0.094,0.188,0.377$, 0.755 , and $1.511 \mathrm{mM})$, SOF combined with RBV $(0.094+0.250,0.188+0.5,0.377+1,0.755+2$, $1.511+4 \mathrm{mM}), \operatorname{SIM}(0.156,0.312,0.625,1.25,2.5$, and $5.0 \mu \mathrm{M})$ and with SIM combined with RBV $(0.156+0.250,0.312+0.5,0.625+1.0,1.25+2.0$ $2.5 \mu \mathrm{M}+4.0 \mathrm{mM})$. After treatment, HepG2 cells were washed twice in Dulbecco's phosphatebuffered saline (DPBS) and cytochalasin B (Cyt B; CAS 14930-96-2; Sigma-Aldrich, St. Louis, MO, USA) was added to a final concentration of 5 $\mu \mathrm{g} / \mathrm{mL}$ in complete fresh medium. Seventy-two hours later, CytB was removed and the cells were washed twice with DPBS at $37^{\circ} \mathrm{C}$, trypsinized with $350 \mu \mathrm{L}$ trypsin (Gibco ${ }^{\circledR}$ Invitrogen, Carlsbad, CA, USA), and resuspended with complete medium. The cells were harvested by cytocentrifugation (Cientec, Belo Horizonte, MG, Brazil). Then, 100 $\mu \mathrm{L}$ of the cell suspension was transferred to cytocentrifuge cups and centrifuged for $5 \mathrm{~min}$ at $151 \times \mathrm{g}$ to produce one spot per slide. Slides were removed, fixed, and stained with Instant Prov (Newprov ${ }^{\circledR}$, Pinhais, PR, Brazil). After staining, slides were air-dried and examined under 400x magnification using a light microscope. Two independent experiments, in duplicate, were performed. Data about treatment of HepG2 cells with RBV alone were previously published by our research group (Librelotto et al. 2019).

The nuclear division cytotoxicity index (NDCl) was estimated by scoring 500 cells with one to four nuclei as well as apoptotic and necrotic cells. The NDCI was calculated using the formula $[\mathrm{Ap}+\mathrm{Nec}+\mathrm{M} 1+2(\mathrm{M} 2)+3(\mathrm{M} 3)+4(\mathrm{M} 4)]$ / 500, where $M 1$ to $M 4$ represent the number of cells with one to four nuclei, respectively, Ap represents the number of apoptotic cells, and $\mathrm{Nec}$ represents the number of necrotic cells. Micronuclei (MNi), nuclear buds (NBUDs), and nucleoplasmic bridges (NPBs) were counted in 1000 binucleated cells (BNC) per experimental point and were scored according to Fenech (2000). The combination index was calculated per each experimental point using the formula $\mathrm{Cl}=[(\mathrm{mA}$ / $m A B)+(m B / m A B)]$, where " $m$ " represents the mean $\mathrm{MNi}$ frequencies induced by each drug alone ( $m A$ or $m B$ ) and in combination ( $m A B$ ). The relationship is characterized as antagonism $(\mathrm{Cl}>1)$, synergism $(\mathrm{Cl}<1)$, or additivity $(\mathrm{Cl}=1)$ (Loewe 1957, Ramakrishnan \& Jusko 2001).

\section{Statistical analysis}

Statistical analysis was performed using the Statistical Package for the Social Sciences (SPSS) software, version 18.0 (SPSS Inc., Chicago, IL, USA). Normality was evaluated with the Kolmogorov-Smirnov test and homogeneity of variance was evaluated with the Levene's test. The results were expressed as the means and standard deviations ( \pm SD). Since NDCl and DNA damage values were not normally distributed, the non-parametric Mann-Whitney $U$ test with $P$ $<0.05$ was used to quantitatively determine the difference between negative control and treated groups.

\section{RESULTS}

$\mathrm{NDCl}$ was calculated for all treatments with SOF, SOF + RBV, SIM, and SIM + RBV as shown in Figures 1 and 2. The treatment with SOF alone (Figure 1a) induced no reduction in NDCl values, 


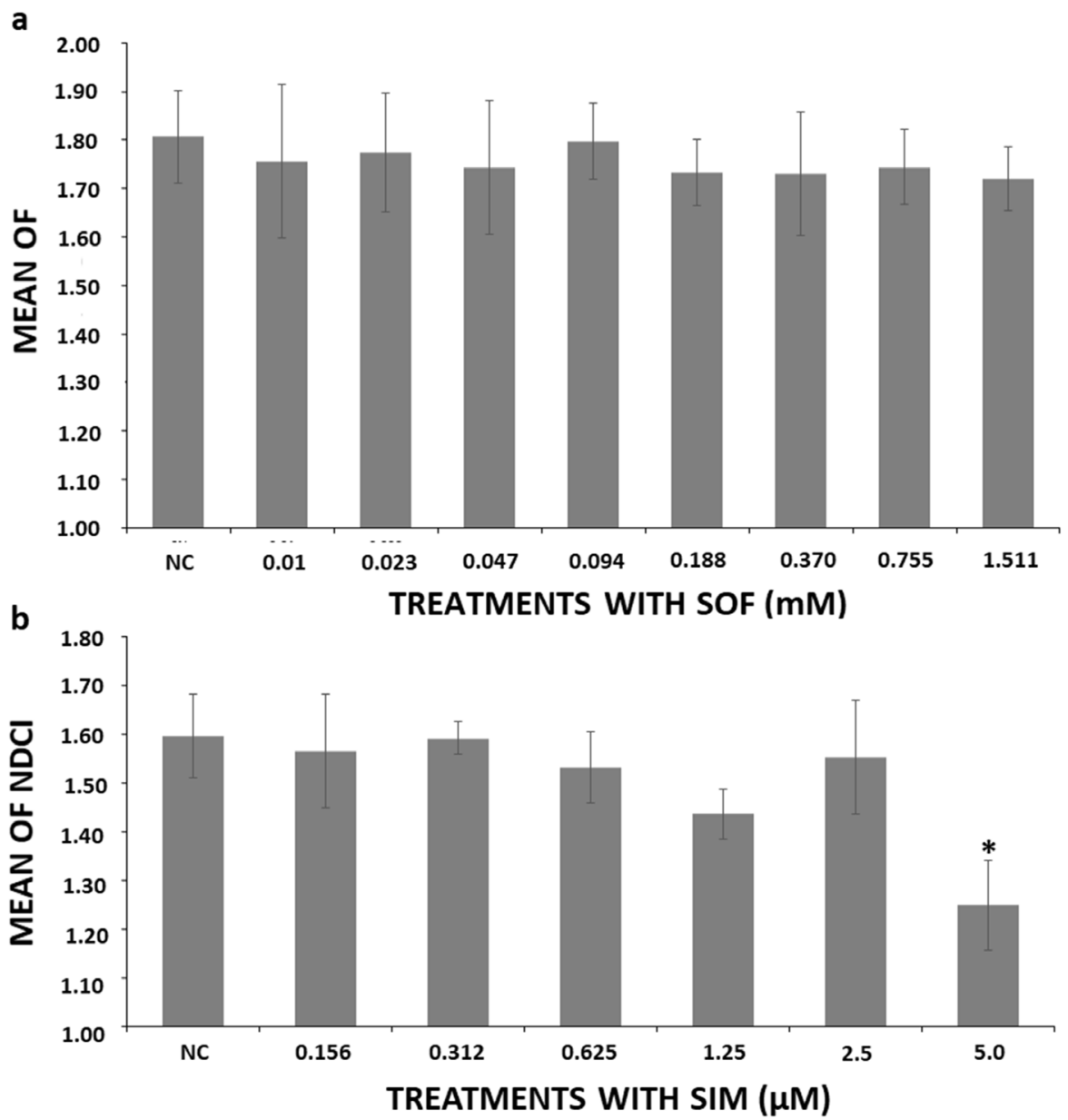

Figure 1. Effects of the exposure of HepG2 cells to (a) sofosbuvir (0.01-1.511 mM) and (b) simeprevir (0.156-5.0 $\mu \mathrm{M})$ on the Nuclear Division Cytotoxicity Index (NDCl). NC, negative control [in (a) DMSO $1 \%$ and in (b) DMEM]; * Significantly different from the NC $(P<0.05)$.

independently of concentration. However, the combined treatment of SOF + RBV (Figure 2a) was able to reduce $\mathrm{NDCl}$ values compared to the negative control, and this reduction was statistically significant for two combined treatments (SOF + RBV: $0.755+2$ and $1.511+4$ $\mathrm{mM}$ ). In the treatment with SIM (Figure 1b), only the highest concentration $(5.0 \mu \mathrm{M})$ significantly reduced the $\mathrm{NDCl}$ values. Likewise, combined treatment of SIM + RBV (Figure 2b) was able to reduce $\mathrm{NDCl}$ values only with the highest concentrations (SIM + RBV: $2.5 \mu \mathrm{M}+4 \mathrm{mM}$ ).

$\mathrm{MNi}, \mathrm{NPBS}$, and NBUDs frequencies were investigated in HepG2 cells using the CBMNCyt assay (Tables I and II). Treatments with SOF alone and combined with RBV (Table I) at the concentrations stipulated did not increase the frequencies of chromosomal damage. The two highest concentrations of the treatment with SIM (1.25 and $2.5 \mu \mathrm{M})$ and four combined treatments (SIM + RBV: $0.312+0.5 ; 0.625+1.0$; $1.25+2.0 ; 2.5 \mu \mathrm{M}+4.0 \mathrm{mM}$ ) induced significant increments in the MNis frequency, compared to the negative control (Table II). When comparing the induction frequencies of both treatments at each concentration, it can be seen that the combined treatment (SIM + RBV) led to significant increases in frequency of MNis compared with the treatment with SIM alone. Frequencies of NPBS and NBUDs were also investigated in HepG2 cells using the CBMN-Cyt assay, but there was no significant increase of these parameters at the concentrations analyzed in the treatments (Tables I and II). 
a

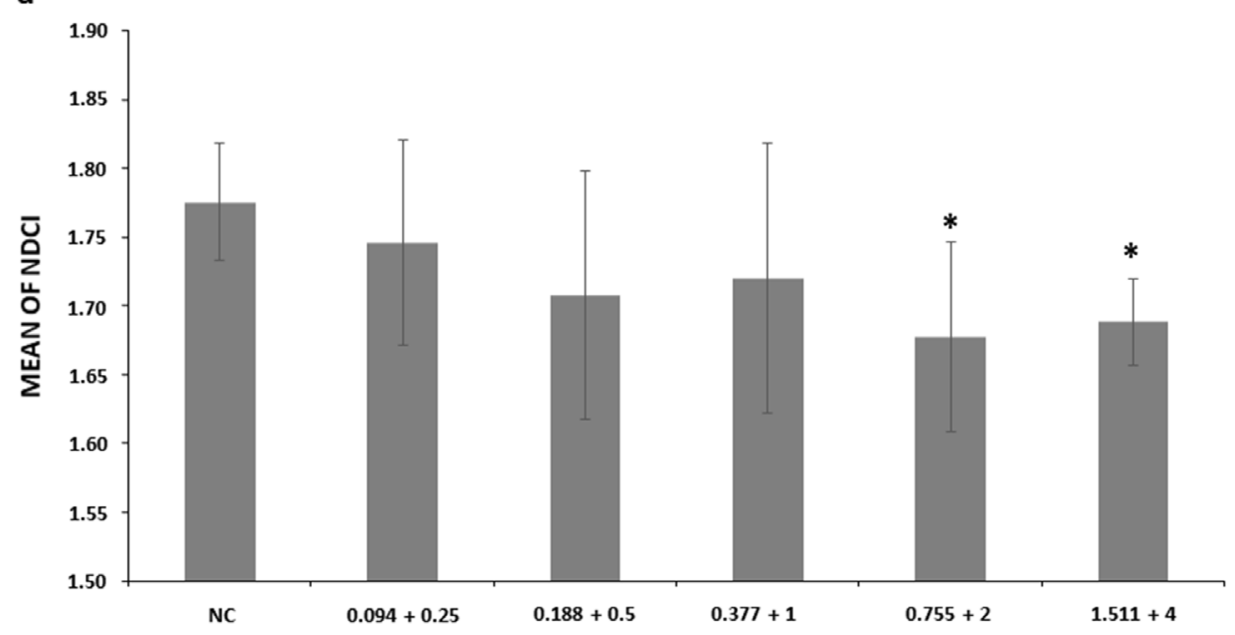

b

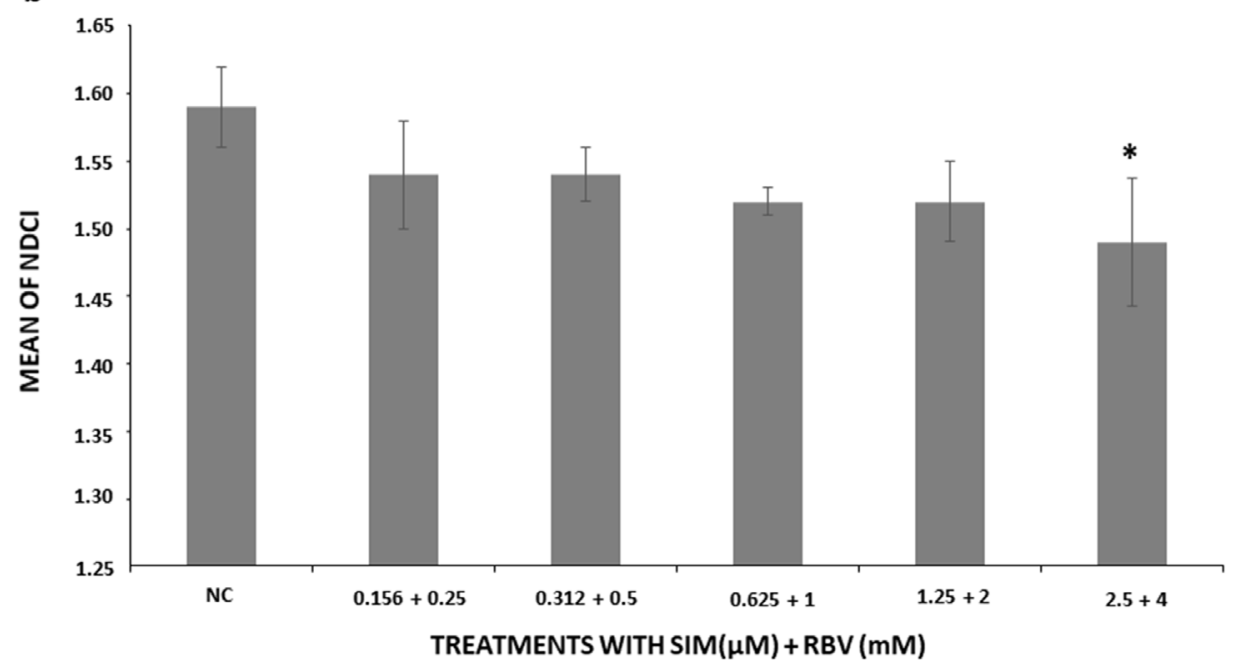

Figure 2. Effects of the exposure of HepG2 cells to (a) sofosbuvir combined with ribavirin and to (b) simeprevir combined with ribavirin on the Nuclear Division Cytotoxicity Index (NDCI). NC, negative control [in (a) DMSO $1 \%$ and in (b) DMEM]; * Significantly different from the NC $(P<0.05)$.
Figure 3 shows the comparison of $\mathrm{MNi}$ frequencies induced by isolated (SOF, SIM and RBV) and combined (SOF + RBV, and SIM + RBV) treatments. Regarding MNi frequency, the isolated treatment with RBV differed significantly from the treatment combined with SOF at all concentrations $(0.25,0.5,1,2$ and $4 \mathrm{mM}$ ) (Figure $3 a)$ and also from the combined treatment with SIM at four concentrations $(0.25,0.5,1$, and 2 $\mathrm{mM}$ ) (Figure 3b). Only two concentrations of the treatment isolated with either SOF ( 0.188 and $0.755 \mathrm{mM}$ ) or SIM (0.156 and $2.5 \mu \mathrm{M}$ ) presented a statistically significant difference compared to the combined treatment with RBV. However, these differences are opposite. Treatment with SOF
(0.188 and $0.755 \mathrm{mM}$ ) caused more chromosome damage, expressed as the frequency of $\mathrm{MNi}$, than the SOF + RBV combination. On the other hand, cells treated with SIM (0.312 and $2.5 \mu \mathrm{M}$ ) showed less chromosomal damage than those treated with SIM + RBV. The combination index showed that both combined treatment (SOF + RBV and SIM + RBV) had antagonistic effects regarding $\mathrm{MNi}$ frequency.

\section{DISCUSSION}

Due to the great epidemiological importance of chronic hepatitis $\mathrm{C}$ worldwide and to the 
Table I. Cytokinesis-block micronucleus (CBMN) cytome assessment of sofosbuvir alone and combined with ribavirin in HepG2 cells.

\begin{tabular}{|c|c|c|c|}
\hline \multirow[t]{2}{*}{ Treatments } & \multicolumn{3}{|c|}{ Chromosomal Damage } \\
\hline & $\mathrm{MNi}^{\mathrm{a}}$ & NPBs $^{\mathrm{a}}$ & NBUDs $^{a}$ \\
\hline \multicolumn{4}{|c|}{ Sofosbuvir } \\
\hline NC & $8.25 \pm 3.45$ & $0.50 \pm 0.50$ & $1.75 \pm 0.71$ \\
\hline $\mathrm{CP}(\mathrm{B}[\mathrm{a}] \mathrm{P} 1 \mu \mathrm{M})$ & $21.00 \pm 6.24^{b}$ & $0.0 \pm 0.0$ & $12.00 \pm 5.00^{b}$ \\
\hline $0.094 \mathrm{mM}$ & $9.13 \pm 3.36$ & $0.50 \pm 0.50$ & $1.88 \pm 1.64$ \\
\hline $0.188 \mathrm{mM}$ & $10.00 \pm 2.19$ & $0.0 \pm 0.0$ & $2.67 \pm 2.31$ \\
\hline $0.377 \mathrm{mM}$ & $9.50 \pm 3.66$ & $0.0 \pm 0.0$ & $1.75 \pm 1.50$ \\
\hline $0.755 \mathrm{mM}$ & $8.67 \pm 2.34$ & $0.0 \pm 0.0$ & $1.00 \pm 0.0$ \\
\hline $1.511 \mathrm{mM}$ & $7.29 \pm 4.54$ & $0.0 \pm 0.0$ & $2.00 \pm 1.41$ \\
\hline \multicolumn{4}{|c|}{ Sofosbuvir and Ribavirin } \\
\hline NC & $4.50 \pm 1.76$ & $0.0 \pm 0.0$ & $0.50 \pm 0.50$ \\
\hline $\mathrm{CP}(\mathrm{B}[\mathrm{a}] \mathrm{P} 1 \mu \mathrm{M})$ & $19.25 \pm 6.18^{b}$ & $0.50 \pm 0.50$ & $9.50 \pm 6.45^{b}$ \\
\hline $0.094 \mathrm{mM}+0.250 \mathrm{mM}$ & $6.00 \pm 3.03$ & $0.0 \pm 0.0$ & $0.50 \pm 0.50$ \\
\hline $0.188 \mathrm{mM}+0.5 \mathrm{mM}$ & $4.16 \pm 2.13$ & $0.50 \pm 0.50$ & $0.0 \pm 0.0$ \\
\hline $0.377 \mathrm{mM}+1 \mathrm{mM}$ & $7.16 \pm 3.76$ & $0.50 \pm 0.50$ & $0.75 \pm 0.30$ \\
\hline $0.755 \mathrm{mM}+2 \mathrm{mM}$ & $3.00 \pm 1.00$ & $0.50 \pm 0.50$ & $0.0 \pm 0.0$ \\
\hline $1.511 \mathrm{mM}+4 \mathrm{mM}$ & $4.75 \pm 0.95$ & $0.0 \pm 0.0$ & $0.50 \pm 0.50$ \\
\hline
\end{tabular}

NC: negative control (DMSO 1\%, dimethyl sulfoxide): PC (B[a]P $1 \mu$ M): positive control (benzo[a]pyrene), MNi: micronuclei, NPBs: nucleoplasmic bridges, NBUDs: nuclear buds.

${ }^{\text {a }}$ Values are given as mean \pm standard deviation.

${ }^{\mathrm{b}}$ Significantly different from the negative control group $(\mathrm{P}<0.05)$ (Mann-Whitney U).

clinical importance of the new treatment for HCV (Wiktor \& Scott 2017), our study provides relevant information about the cytotoxic and genotoxic profile of SOF and SIM, alone and in combination with RBV, using the in vitro CBMN-Cyt assay in HepG2 cells. In the selected concentrations, it was possible to observe the absence of cytotoxic and genotoxic effects of SOF both alone and combined with RBV. In contrast, SIM alone and combined with RBV showed cytotoxic and genotoxic effects. Besides, SOF and SIM presented antagonistic effects to the well-documented genotoxic effects of RBV.

Cytotoxic effects were measured by $\mathrm{NDCl}$ in all treatments, and only the cells exposed to the highest concentration of SIM exhibited significantly reduced cell proliferation compared to the negative control. For this reason, the chromosomal damage was not evaluated for this concentration. It is possible that these results were caused by RBV. In vitro genotoxicity studies using cultured human lymphocytes (Joksić et al. 2000, 2006), CHO-K1 (Chinese hamster ovary), and HepG2 cells (Librelotto et al. 2019) also demonstrated that different RBV concentrations inhibit cell proliferation. It has been proposed that the cytotoxic effect of RBV is due to induction of cell death and suppression of cell division and proliferation (D'Souza \& Narayana 2002).

The results observed in our study demonstrated that treatments with SOF, alone and combined with RBV, did not increase the frequency of chromosomal damage (MNi, NPBS, NBUDs) independently of dose. These results, regarding the absence of genotoxic effect of 
Table II. Cytokinesis-block micronucleus (CBMN) cytome assessment of simeprevir alone and combined with ribavirin in HepG2 cells.

\begin{tabular}{|c|c|c|c|}
\hline \multirow{2}{*}{ Treatments } & \multicolumn{3}{|c|}{ Chromosomal Damage } \\
\hline & $\mathrm{MNi}^{\mathrm{a}}$ & NPBs $^{\mathrm{a}}$ & NBUDs $^{\mathrm{a}}$ \\
\hline \multicolumn{4}{|c|}{ Simeprevir } \\
\hline $\mathrm{NC}\left(\mathrm{DMEM}+\mathrm{H}_{2} \mathrm{O}\right)$ & $3.75 \pm 1.26$ & $0.0 \pm 0.0$ & $0.0 \pm 0.0$ \\
\hline$P C(B[a] P 1 \mu M)$ & $18.75 \pm 6.80^{\mathrm{b}}$ & $0.50 \pm 0.50$ & $9.50 \pm 6.08^{b}$ \\
\hline $0.156 \mu \mathrm{M}$ & $4.75 \pm 1.26$ & $0.0 \pm 0.0$ & $0.50 \pm 0.50$ \\
\hline $0.312 \mu \mathrm{M}$ & $6.25 \pm 2.63$ & $0.0 \pm 0.0$ & $1.00 \pm 0.0$ \\
\hline $0.625 \mu \mathrm{M}$ & $6.75 \pm 3.10$ & $0.0 \pm 0.0$ & $1.00 \pm 0.0$ \\
\hline $1.25 \mu \mathrm{M}$ & $6.75 \pm 1.71^{b}$ & $0.0 \pm 0.0$ & $0.0 \pm 0.0$ \\
\hline $2.5 \mu \mathrm{M}$ & $7.00 \pm 2.71^{b}$ & $0.0 \pm 0.0$ & $0.50 \pm 0.50$ \\
\hline \multicolumn{4}{|c|}{ Simeprevir and Ribavirin } \\
\hline NC (DMEM) & $4.75 \pm 0.96$ & $0.0 \pm 0.0$ & $0.0 \pm 0.0$ \\
\hline$P C(B[a] P 1 \mu M)$ & $18.75 \pm 6.80^{\mathrm{b}}$ & $0.50 \pm 0.50$ & $9.50 \pm 6.08^{b}$ \\
\hline $0.156 \mu \mathrm{M}+0.25 \mathrm{mM}$ & $5.50 \pm 1.73$ & $0.0 \pm 0.0$ & $0.0 \pm 0.0$ \\
\hline $0.312 \mu \mathrm{M}+0.5 \mathrm{mM}$ & $9.67 \pm 0.58^{b}$ & $0.0 \pm 0.0$ & $0.0 \pm 0.0$ \\
\hline $0.625 \mu \mathrm{M}+1 \mathrm{mM}$ & $8.25 \pm 1.26^{b}$ & $0.0 \pm 0.0$ & $0.0 \pm 0.0$ \\
\hline $1.25 \mu M+2 m M$ & $9.25 \pm 1.71^{b}$ & $0.0 \pm 0.0$ & $0.0 \pm 0.0$ \\
\hline $2.5 \mu \mathrm{M}+4 \mathrm{mM}$ & $14.25 \pm 2.50^{\mathrm{b}}$ & $0.0 \pm 0.0$ & $0.0 \pm 0.0$ \\
\hline
\end{tabular}

NC (DMEM+ $\mathrm{H}_{2} \mathrm{O}$ ): negative control (Dulbecco's Modified Eagle's Medium; water), PC (B[a]P): positive control (benzo[a]pyrene), MNi: micronuclei, NPBs: nucleoplasmic bridges, NBUDs: nuclear buds.

${ }^{a}$ Values are the mean \pm standard deviation.

${ }^{\mathrm{b}}$ Significantly different from the negative control group $(\mathrm{P}<0.05)$ (Mann-Whitney $U$ test).

SOF, are in accordance with data published by American (FDA 2013a) and European (EMA 2016) evaluation reports of SOF. These reports revealed that SOF does not induce any genotoxic effect, as observed in other genotoxicity assays, such as the in vitro reverse mutation assay (bacteria), in vitro chromosome aberration assay (human lymphocytes), and in vivo micronucleus assay. On the other hand, the results found in our study revealed genotoxicity of SIM that is not reported in the full review report of SIM issued by the FDA and EMA (European Medicines Agency). According to FDA (2013b) and EMA (2014), SIM did not show genotoxicity in the following tests: Ames test, L5178Y TK+/- mouse lymphoma cells, and in vivo mouse micronuclei test. Our study, using the CBMN-Cyt assay in HepG2 cells, showed genotoxic effects of SIM at the highest concentrations (1.25 and $2.5 \mu \mathrm{M})$ and in four combinations with RBV (SIM+RBV: $0.312+0.5 ; 0.625+1.0 ; 1.25+2.0 ; 2.5 \mu M+4.0$ $\mathrm{mM})$. SIM alone and combined with RBV may lead to increased $\mathrm{MNi}$ frequencies, indicating the possibility of promoting chromosomal mutations associated to aneugenic and/or clastogenic events in HepG2 cells. The MNis are small, extranuclear bodies observed as a result of chromosome fragmentation (clastogenic) or whole chromosome loss (aneugenic) during cell division and are used as a marker of chromosome damage and instability (Schmid 1975, Fenech \& Morley 1985, Fenech 2000).

In our study, the genotoxic mechanisms of SIM were not investigated, since this was not one of the objectives of the study. Therefore, 
a

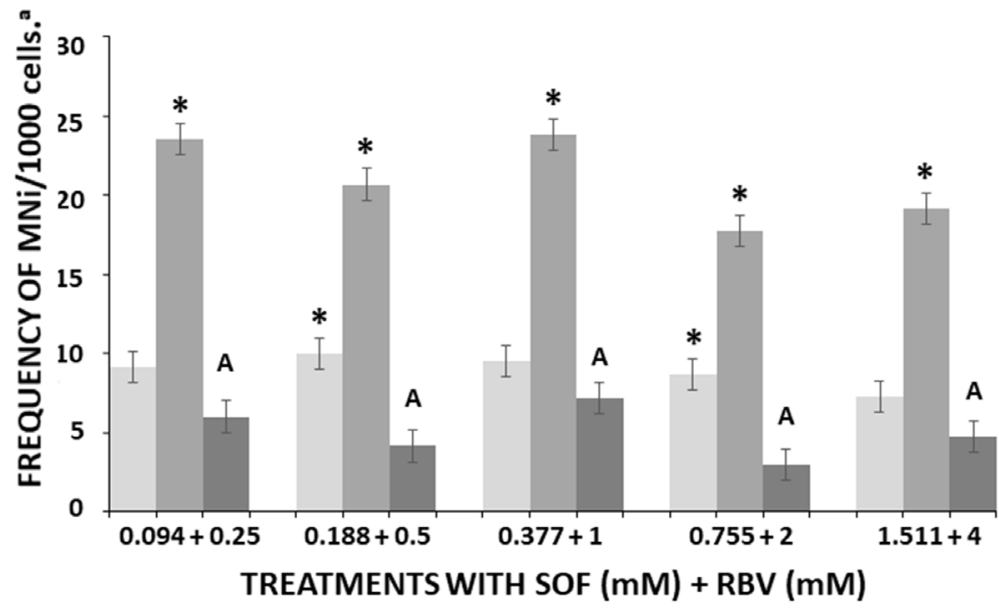

b

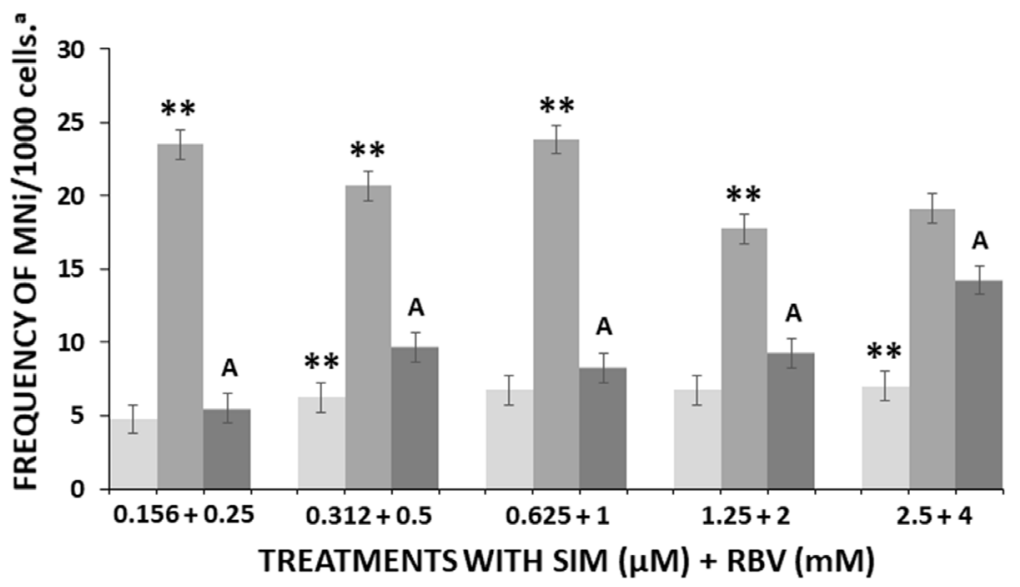

Figure 3. Comparison of the micronuclei frequencies obtained for the treatments with SOF, SIM and RBV used individually and their respective combined treatments. (a): Treatments with SOF, RBV, and SOF + $\mathrm{RBV}$; * Significantly different from the SOF + RBV group $(P<0.05)$ (Mann-Whitney U). (b): Treatments with SIM, RBV, and SIM + RBV; ** Significantly different from the SIM SIM + RBV group $(P<0.05)$

RBV (Mann-Whitney U). A: antagonism, SIM + RBV obtained through the combination index. a: Values are the mean \pm standard deviation. MNi: micronuclei. SOF: sofosbuvir. SIM: simeprevir. RBV: ribavirin. further studies should be performed in order to elucidate these processes. However, it is known that mutagenic chemicals can induce genomic changes in DNA directly or/and indirectly, but some substances need to be metabolized before they acquire their mutagenic capacity (KirschVolders et al. 2003, Mateuca et al. 2006). SIM is metabolized in the liver and in vitro experiments with human liver microsomes indicated that simeprevir primarily undergoes oxidative metabolism by the hepatic CYP3A system (FDA 2013b).

The combination index evaluation demonstrated that SOF and SIM antagonized the genotoxic effects of RBV. These results reveal a significant reduction in MNi frequency after the combined treatment, compared to the treatment with RBV alone. Recently, Librelotto et al. (2019) demonstrated that RBV was genotoxic to CBMNCyt in HepG2 and CHO-K1 cells, and other studies have also clarified the genotoxic profile of RBV (Joksić et al. 2000, 2006, D'Souza \& Narayana 2002). Although such antagonism mechanisms were not evaluated in the present study, our results are of considerable importance, since they demonstrate that the combination of RBV with SOF and SIM decreases the welldocumented genotoxicity of RBV when used alone. Studies demonstrate that SOF and SIM are substrate/inhibitor for the efflux transporter P-glycoprotein (de Kanter et al. 2014, Kirby et al. 2015, Ouwerkerk-Mahadevan et al. 2016), and this glycoprotein is expressed on the surface of HepG2 cells (Cantz et al. 2000, Decaens et 
al. 2008). Due to unknown mechanisms, an influence on RBV absorption/metabolism could occur when RBV and SOF or RBV and SIM are combined (Chan et al. 2004).

Since several treatment regimens are based on the combination SOF + RBV, the conjoint use of these drugs should be studied in detail. Moreover, particularly in clinical practice, it is important to know more about the genotoxic effects of DAAs, since these drugs can be used by various age groups, each characterized by their own epidemiological profiles. For example, a large number of HCV patients is also infected with the human immunodeficiency virus (HIV), in view of transmission routes both viruses share (Peters \& Klein 2015). HIV-infected patients often use antiretroviral drugs with known genotoxic effects (Schilling et al. 1995, Von Tungeln et al. 2004, Carter et al. 2007, Torres et al. 2007, Guimarães et al. 2013). The combined use of DAA and antiretroviral drugs has been evaluated primarily regarding the potential drug-drug interactions and overlapping toxicities (Soriano et al. 2017), but there is no data on the risk of DNA damage caused by combination of these drugs.

One of the limitations of the present study was that the highest concentration of SOF stipulated is factually restricted by the maximum concentration allowed for the solvent in the culture (1\% DMSO) (OECD 487 2016). In other words, the absence of cytotoxicity observed for the highest concentration of SOF used was possibly due to the fact that we could not further evaluate the effects of higher levels of the drug.

In conclusion, exposure of HepG2 cells to SOF and SOF + RBV did not induce cytotoxicity, chromosomal damage, or complex genomic changes. In contrary, SIM alone and associated with RBV has the ability to cause genotoxic effects independently of the doses used. In addition, the combination index demonstrated the antagonistic effect of SOF and SIM on the genotoxic effects caused by RBV. Considering the great importance of SOF-based treatment regimens in HCV therapy, our results are relevant in that they demonstrate the genotoxic safety profile of SOF and its combination with RBV.

\section{Acknowledgments}

This work was supported by Coordenação de Aperfeiçoamento de Pessoal de Nivel Superior (CAPES - PROSUP; Finance Code 001), Conselho Nacional de Desenvolvimento Científico e Tecnológico (CNPq) and Universidade Luterana do Brasil (ULBRA).

\section{REFERENCES}

BECK KR, KIM N \& KHALILI M. 2016. Sofosbuvir-containing regimens for chronic hepatitis $C$ are successful in the safety-net population: a real-world experience. Dig Dis Sci 61: 3602-3608.

CALLEJA JL ET AL. 2017. Effectiveness, safety and clinical outcomes of direct-acting antiviral therapy in HCV genotype 1 infection: Results from a Spanish real-world cohort. J Hepatol 66: 1138-1148.

CANTZ T, NIES AT, BROM M, HOFMANN AF \& KEPPLER D. 2000. MRP2, a human conjugate export pump, is present and transports fluo 3 into apical vacuoles of Hep G2 cells. Am J Physiol Gastrointest Liver Physiol 278(4): G522-G531.

CARTER MM, TORRES SM, COOK DL JR, MCCASH CL, YU M, WALKER VE \& WALKER DM. 2007. Relative mutagenic potencies of several nucleoside analogs alone or in drug pairs at the HPRT and TK loci of human TK6 lymphoblastoid cells. Environ Mol Mutagen 48: 239-247.

CHAN LM, LOWES S \& HIRST BH. 2004. The ABCS of drug transport in intestine and liver: efflux proteins limiting drug absorption and bioavailability. Eur J Pharm Sci 21(1): 25-51.

CRESPO J ET AL. 2017. Real-world effectiveness and safety of oral combination antiviral therapy for hepatitis $C$ virus genotype 4 infection. Clin Gastroenterol Hepatol 15: $945-949$.

DECAENS C, DURAND M, GROSSE B \& CASSIO D. 2008. Which in vitro models could be best used to study hepatocyte polarity?. Biol Cell 100(7): 387-398.

DE KANTER CT, DRENTH JP, ARENDS JE, REESINK HW, VAN DER VALK M, DE KNEGT RJ \& BURGER DM. 2014. Viral hepatitis C therapy: 
pharmacokinetic and pharmacodynamic considerations. Clin Pharmacokinet 53(5): 409-427.

D'SOUZA UJ \& NARAYANA K. 2002. Mechanism of cytotoxicity of ribavirin in the rat bone marrow and testis. Indian J Physiol Pharmacol 46: 468-474.

EMA. 2014. Assessment report. International nonproprietary name: simeprevir; Procedure No. EMEA/ H/C/002777/0000; 2014. Available from: http://www. ema.europa.eu/docs/en_GB/document_library/ EPAR_-_Public_assessment_report/human/002777/ WC500167870.pdf (May 21, 2019).

EMA. 2016. Assessment report. International nonproprietary name: sofosbuvir/velpatasvir. Procedure No. EMEA/H/C/004210/0000. Available from: http:// www.ema.europa.eu/docs/en_GB/document_library/ EPAR_Public_assessment_report/human / 004210/ WC500211152.pdf (May 21, 2019).

FDA. 2013a. Center for Drug Evaluation and Research. Application number: 2046710 rig1s000. Pharmacology Review(s). Available from: https:// www.accessdata.fda.gov/drugsatfda_docs / nda/2013/2046710rig1s000PharmR.pdf (May 21, 2019).

FDA. 2013b. Center for Drug Evaluation and Research; Application number: 2051230rig1s000; Pharmacology Review(s); 2013. Available from: https://www.accessdata.fda.gov/drugsatfda_docs/ nda/2013/2051230rig1s000PharmR.pdf (May 21, 2019).

FENECH M. 2000. The in vitro micronucleus technique. Mutat Res 455: 81-95.

FENECH M. 2006. Cytokinesis-block micronucleus assay evolves into a "cytome" assay of chromosomal instability mitotic dysfunction and cell death. Mutat Res 600: 58-66.

FENECH M. 2007. Cytokinesis-block micronucleus cytome assay. Nat Protoc 2: 1084-1104.

FENECH M \& MORLEY AA. 1985. Measurement of micronuclei in lymphocytes. Mutat Res 147: 29-36.

FLISIAK R ET AL. 2017a. Effectiveness and safety of ledipasvir/sofosbuvir \pm ribavirin in the treatment of $\mathrm{HCV}$ infection: The real-world HARVEST study. Adv Med Sci 62: 387-392.

FLISIAK R, POGORZELSKA J \& FLISIAK-JACKIEWICZ M. 2017b. Hepatitis C: efficacy and safety in real life. Liver Int 37 (Suppl 1): 26-32.

GEDDAWY A, IBRAHIM YF, ELBAHIE NM \& IBRAHIM MA. 2017. Direct Acting Anti-hepatitis C Virus Drugs: Clinical Pharmacology and Future Direction. J Transl Int Med 5: 8-17.
GONZÁLEZ-GRANDE R, JIMÉNEZ-PÉREZ M, GONZÁLEZ ARJONA C \& MOSTAZO TORRES J. 2016. New approaches in the treatment of hepatitis C. World J Gastroenterol 22: 1421-1432.

GUIMARÃES NN, SILVA CJ, DE ANDRADE HH, DIHL RR, LEHMANN M \& CUNHA KS. 2013. Comparative analysis of genetic toxicity of antiretroviral combinations in somatic cells of Drosophila melanogaster. Food Chem Toxicol 53: 299-309.

JACOBSON IM ET AL. 2011. Telaprevir for previously untreated chronic hepatitis C virus infection. N Engl J Med 364: 2405-2416.

JOKSIĆ G, STANKOVIĆ M, VASIĆ V, CAKAR M \& JOKANOVIĆ M. 2000. Influence of ribavirin on the micronucleus formation and in vitro proliferation of human lymphocytes. Neoplasma 47: 283-287.

JOKSIĆ I, LESKOVAC A, PETROVIĆ S \& JOKSIĆ G. 2006. Vitamin B12 reduces ribavirin-induced genotoxicity in phytohemaglutinin-stimulated human lymphocytes. Tohoku J Exp Med 209: 347-354.

KIRBY BJ, SYMONDS WT, KEARNEY BP \& MATHIAS AA. 2015. Pharmacokinetic, Pharmacodynamic, and DrugInteraction Profile of the Hepatitis C Virus NS5B Polymerase Inhibitor Sofosbuvir. Clin Pharmacokinet 54(7): 677-690.

KIRSCH-VOLDERS M, VANHAUWAERT A, EICHENLAUB-RITTER U \& DECORDIER I. 2003. Indirect mechanisms of genotoxicity. Toxicol Lett 140-141: 63-74.

LIBRELOTTO CS, SIMON D, DE SOUZA AP, ÁLVARES-DA-SILVA MR \& DIHL RR. 2019. Chromosomal instability and cytotoxicity induced by ribavirin: comparative analysis in cell lines with different drug-metabolizing profiles. Drug Chem Toxicol 42: 343-348.

LIU X, WANG Y, ZHANG G, LI N, ZHU Q, CHANG H, HAN Q, LV Y \& LIU Z. 2014. Efficacy and safety of sofosbuvir-based therapy for the treatment of chronic hepatitis $C$ in treatment-naïve and treatment-experienced patients. Int J Antimicrob Agents 44: 145-151.

LOEWE S. 1957. Antagonism and antagonist. Pharmacol Rev 9: 237-242.

MATEUCA R, LOMBAERT N, AKA PV, DECORDIER I \& KIRSCHVOLDERS M. 2006. Chromosomal changes: induction detection methods and applicability in human biomonitoring. Biochimie 88: 1515-1531.

OECD. 2016. Guidelines for the Testing of Chemicals. In Vitro Mammalian Cell Micronucleus Test (487). Available from: http://www.oecd-ilibrary.org/environment/ test-no-487-in-vitro-mammalian-cell-micronucleustest_9789264264861-en (September 9, 2016). 
OUWERKERK-MAHADEVAN S, SNOEYS J, PEETERS M, BEUMONTMAUVIEL M \& SIMION A. 2016. Drug-Drug Interactions with the NS3/4A Protease Inhibitor Simeprevir. Clin Pharmacokinet 55(2): 197-208.

PETERS L \& KLEIN MB. 2015. Epidemiology of hepatitis C virus in HIV-infected patients. Curr Opin HIV AIDS 10: 297-302.

POORDAD F ET AL. 2011. Boceprevir for untreated chronic HCV genotype 1 infection. N Engl J Med 364: 1195-1206.

RAMAKRISHNAN R \& JUSKO WJ. 2001. Interactions of aspirin and salicylic acid with prednisolone for inhibition of lymphocyte proliferation. Int Immunopharmacol 1: 2035-2042.

SCHILLING BE, NELSON DR, PROCTOR JE, DIAMOND SS, KAUL S \& HAWKINS HC. 1995. The nonclinical toxicologic profile of stavudine. Curr Ther Res 56: 201-218.

SCHMID W. 1975. The micronucleus test. Mutat Res 31: 9-15.

SEBASTIANI G, GKOUVATSOS K \& PANTOPOULOS K. 2014. Chronic hepatitis C and liver fibrosis. World J Gastroenterol 20: 11033-11053.

SORIANO V, LABARGA P, FERNANDEZ-MONTERO JV, MENDOZA C, BENITEZ-GUTIÉRREZ L, PEÑA JM \& BARREIRO P. 2017. Drug interactions in HIV-infected patients treated for hepatitis C. Expert Opin Drug Metab Toxicol 13: 807-816.

TORRES SM, WALKER DM, CARTER MM, COOK DL JR, MCCASH CL, CORDOVA EM, OLIVERO OA, POIRIER MC \& WALKER VE. 2007. Mutagenicity of zidovudine lamivudine and abacavir following In vitro exposure of human lymphoblastoid cells or in utero exposure of CD-1 mice to single agents or drug combinations. Environ Mol Mutagen 48: 224-238.

VON TUNGELN LS, DOBROVOLSKY VN, BISHOP ME, SHADDOCK JG, HEFLICH RH \& BELAND FA. 2004. Frequency of Tk and Hprt lymphocyte mutants and bone marrow micronuclei in mice treated neonatally with zidovudine and didanosine. Mutagenesis 19: 307-311.

WHO. 2017. Global hepatitis report, 2017. Available from: http://www.who.int/hepatitis/publications/globalhepatitis-report2017/en/ (May 21, 2019).

WIKTOR SZ \& SCOTT JD. 2017. What is the impact of treatment for hepatitis C virus infection? Lancet 390: 107-109.

YANG YM \& CHOI EJ. 2017. Efficacy and safety outcomes of sofosbuvir-based treatment regimens for hepatitis $C$ virus-infected patients with or without cirrhosis from phase III clinical trials. Ther Clin Risk Manag 13: 477-497.

\section{How to cite}

LIBRELOTTO CS, SOUZA AP, ÁLVARES-DA-SILVA MR, SIMON D \& DIHL RR. 2021. Evaluation of the genetic toxicity of sofosbuvir and simeprevir with and without ribavirin in a human-derived liver cell line. An Acad Bras Cienc 93: e20200632. DOI 10.1590/0001-3765202120200632.

Manuscript received on April 27, 2020;

accepted for publication on July 3, 2020

\section{CARINA S. LIBRELOTTO ${ }^{1}$}

https://orcid.org/0000-0002-7194-4653

\section{ANA PAULA DE SOUZA ${ }^{1}$}

https://orcid.org/0000-0003-3297-1058

\section{MÁRIO R. ÁLVARES-DA-SILVA}

https://orcid.org/0000-0002-5001-246X

\section{DANIEL SIMON}

https://orcid.org/0000-0003-1122-8468

\section{RAFAEL R. DIHL ${ }^{1}$}

https://orcid.org/0000-0003-4491-5870

${ }^{1}$ Programa de Pós-Graduação em Biologia Celular e Molecular Aplicada à Saúde, Universidade Luterana do Brasil (ULBRA), PPG Biologia Celular e Molecular Aplicada à Saúde, Av. Farroupilha, 8001, Prédio

22, $4^{\circ}$ andar, 92425-900 Canoas, RS, Brazil

${ }^{2}$ Programa de Pós-Graduação Ciências em Gastroenterologia e Hepatologia, Universidade Federal do Rio Grande do Sul (UFRGS), Hospital das Clínicas de Porto Alegre, Rua Ramiro Barcelos, 2350, Santa Cecilia, 90035-007 Porto Alegre, RS, Brazil

Correspondence to: Rafael R. Dihl

E-mail: rafael.rodrigues@ulbra.br

\section{Author contributions}

Carina Sperotto Librelotto: conceived and designed the experiments, performed the experiments, analyzed the data, performed the literature review and wrote the paper. Ana Paula de Souza: performed the experiments, analyzed the data and wrote the paper. Mário Reis Álvares-da-Silva: contributed materials and wrote the paper. Rafael Rodrigues Dihl: designed the experiments, contributed reagents and materials, analyzed the data and wrote the paper. Daniel Simon: analyzed the data and wrote the paper.

\section{(cc) BY}

